\title{
The Christian call for building unity
}

Jesus established "the greatest" (Matthew) and "the first" (Mark) double commandment of: love for God and for neighbour, treating them equally, positioning one next to the other. Both commandments had existed in the Old Testament, yet separately. Jesus' alternative is based on two biblical citations: "Hear, O Israel: The Lord our God is one Lord; and you shall love the Lord your God with all your heart, and with all your soul, and with all your might"1 and "The stranger who sojourns with you shall be to you as the native among you, and you shall love him as yourself; for you were strangers in the land of Egypt: I am the Lord your God." ${ }^{2}$ The expression of "loving God with all one's heart and all one's soul" implies the intensity and comprehensiveness of love. In the Hebrew language "soul" very often meant "life," therefore "love for God with all your soul" signified love until the sacrifice of one's life. ${ }^{3}$

* Rev. Professor Andrzej Zwoliński, a habilitated doctor, born in 1957, Head of the Department of Catholic Social Science at the Faculty of Social Sciences of the Pontifical University of John Paul II in Krakow. As a lecturer and essayist, his main field of academic expertise is political science, business ethics, the history of ideas, and sociology of culture.

1 Deut 6:4-5.

2 Lev 19:34.

3 Cf. E. Dąbrowski, Nowy Testament na tle epoki. Geografia - historia - kultura, Poznań 1965. 


\section{A neighbour and a stranger}

Hospitality was nothing unusual amongst the first Christians; it was the most cardinal, the most frequently practiced and the most commendable quality. It contained the very essence of the love commandment in practical use. Hospitality is connected with the meaning of foreignness, as it most often applied to inviting strangers, whilst the presence of "ours" at the table was commonly acceptable and completely natural. "A stranger," invited to the meal, became "a guest" rapturously welcome to the house, its riches and its table. Hospitality is thus the attitude of openness and kindness to another man. Its main implication is the way of understanding man, the appropriate philosophical anthropology according to which man is viewed as a person, an individual, separate, self-contained and unique bodily-and-spiritual entity, endowed with the ability to live an organic and intellectual-and-volitional life, manifested through science, art, moral and religious conduct. ${ }^{4}$ Another attribution of hospitality, in its personalist sense, derives from the basic psychological and spiritual needs, including the need for so called affiliation with a circle of people, the need for dialogue and communication, for expressing one's own thoughts and emotions, for enriching and completing one another, for remedying one's shortcomings and overcoming one's limitations, for experiencing joy and even happiness from meeting other people. ${ }^{5}$

The personal dignity, so to speak, inbred in a guest, implicate the following prescriptions, the most essential of which are:

1. Avoiding such means of addressing guests which might suggest our instrumental, utilitarian attitude, typical of objectification,

2. The necessity of showing respect and kindness to all people living next to us, asking for help, in place of vastly disproportionate treatment depending on their social rank or material status, and

3. Love as the only suitable point of reference and which each person deserves; it is often an elemental act of justice - the act of restitution, when

4 Cf. K. H. Schelkle, Teologia Nowego Testamentu, tłum. M. L. Dylewski, Kraków 1984.

5 Cf. E. Mounier, Wprowadzenie do egzystencjalizmów, tłum. A. Bukowski, E. Krasnowolska, Kraków 1964, pp. 37ff; A. Rodziński, Osoba. Moralność. Kultura, Lublin 1989, pp. 216217; K. Wojtyła, Rozważania o istocie człowieka, Kraków 1999, pp. 95-97. 
we want to express our gratitude for hospitality and kindness or reparation of harms and damages done. ${ }^{6}$

The word "guest" originates from the Latin hospes - hence the terms hospitality and guest. Already in the $16^{\text {th }}$ century did it denote a newcomer, a foreigner, a seasonal dweller, a pilgrim, a wanderer, generally speaking, a "stranger." As early as in Homer's times was hospitality a requirement of court etiquette, establishing the rule of reciprocity, guaranteed by property ownership. In Iliad, hospitality is a moral obligation commanded by Zeus - the protector of guests (XI, 779; XIII, 624). A guest (Greek: xenos) was entitled with more rights to help on a battlefield than, for instance, a so called supplicant (Greek: hiketes). Denial of hospitality was an offence punishable by gods, and murdering a guest was crime against gods (VI, 167). Even a supplicant who had been excluded from his community for the committed crime, had the right to hospitality from strangers. A similar right was granted to envoys sent to enemies (I, 334; XI, 779). The right to hospitality was not waived even by war, and friendships, along with all their duties, established by fathers, were cultivated by their sons (VI, 212-236). The right to hospitality was also given to travellers, and even to beggars who also remained under Zeus's protection. ${ }^{7}$

In the Holy Bible an exemplar of hospitality is God Himself, who is unbiased and just, and who gives Israel the order of loving a sojourner, ${ }^{8}$ of welcoming him in the name of mercy. ${ }^{9}$ Therefore the right to hospitality bore a religious feature. A stranger was regarded as a guest of God Himself, who reminds that: "The land shall not be sold in perpetuity, for the land is mine; for you are strangers and sojourners with me."10 God justifies this command by making Israelis remember that they also were once foreigners in the land of Egypt. ${ }^{11} \mathrm{~A}$ paradigm of hospitality is the demeanour of Abraham ${ }^{12}$ and Job, ${ }^{13}$ whilst an example of relinquishing it - the behaviour of Sodomites. ${ }^{14} \mathrm{~A}$ guest is entitled to and

6 Cf. K. Mikucki, Od obcego do gościa. Refleksje socjologiczno-filozoficzne, in: Hospitalitas consecrata, red. K. Wójtowicz, Kraków 2003, pp. 56-68.

7 H. Wójtowicz, Gościnność, in: Encyklopedia katolicka, t. 5, Lublin 1989, k. 1334-1335.

8 Deut 10:18-19.

9 Isa 58:7; Sir 29:21-28.

10 Lev 25:23.

11 Ex 22:21; Lev 19:33-34.

12 Gen 18:1-8.

13 Job 31:32.

14 Gen 19:1-8; Wis 19:13-15; cf. Judg 5:24-27, 19:1-30. 
remains under the host's protection, while the latter is obliged to accommodate him and to put the hospitality law over his own and his kin's good.

\section{A sojourner in the Church}

In the New Testament Jesus re-endorses full rights to hospitality and encourages it. ${ }^{15}$ The Kingdom which Jesus proclaims is very often depicted as a solemn feast to which all are invited. ${ }^{16}$ The promised Kingdom is to be a joyous reception at God's Home. Jesus Himself experienced hospitality many a time, the example of which may be a visit to Martha and Mary. ${ }^{17}$ In His teaching Jesus very often identifies Himself with a guest. ${ }^{18}$ Hospitality has accordingly become one of the criteria of the Christian life and conduct. ${ }^{19}$ It was also the foundation on which the domestic Churches and missionary works were founded. ${ }^{20}$ The idea of the Church has encompassed hospitality as the manifestation of brotherly love. ${ }^{21}$

The Church Fathers deemed hospitality as a Christian value. The Didache (No. 12) prescribes housing every guest coming in the name of Jesus. Pope Clement I addressed hospitable and prosperous Corinthians whom he strengthened with the biblical teaching on generosity, regarding inhospitality as one of the gravest sins. As claimed by The Shepherd of Hermas, hospitality offers a chance to do good works, save sinners from damnation and is an essential duty of a bishop. When referring to the gifts offered during the Eucharist, Saint Justin reminds us that a bishop shares them with orphans, widows, the sick, prisoners and strangers (St. Justin M., Apol 1.67). The rule of hospitality was to be followed by the community of the faithful, including the monastic ones. Deceased in 346 AD, Saint Pachom - the father of the

15 Lk 7:44-46; 14: 12-14.

16 Mt 8:11; 22:1-14; cf. Lk 14:16-24.

17 Lk 10:38-42.

18 Mt 10:40; 25:35. 38.43-44.

19 Gen 12:13; 1 Tim 3:2; 5: 10; Titus 1:8; 1 Pet 4:9.

20 Mt 10:11-13; 3 Jn 1:10.

21 W. Popielewski, Gościnność w ikonach i nakazach biblijnych, in: Hospitalitas consecrata..., pp. 38-55; Cf. J. K. Pytel, Pojęcie gościnności w literaturze biblijnej, "Ruch Biblijny i Liturgiczny" 1977 nr 30, pp. 174ff; A. Paciorek, Obyczajowość życia wspólnotowego, in: Życie społeczne w Biblii, red. G. Witaszek, Lublin 1997, pp. 314-320. 
Christian monasteries - in his rule prescribed for his followers, obliged monastic communities to offer hospitality, recommending to appoint one brother to deal with the matters of accommodation. ${ }^{22}$ Circa $530 \mathrm{AD}$ the Rule of St. Benedict was developed which by $813 \mathrm{AD}$ was applied in all the monasteries of the Carolingian Monarchy. The well-known $53^{\text {rd }}$ chapter of it is entitled: On the reception of guests. We read in it: "Let all guests who arrive be received like Christ, for He is going to say: 'I came as a guest, and you received $\mathrm{Me}^{\prime}$ (Matt. 25:35). And to all let due honour be shown, especially to the domestics of the faith and to pilgrims. As soon as a guest is announced, therefore, let the Superior or the brethren meet him with all charitable service. And first of all let them pray together, and then exchange the kiss of peace." ${ }^{23}$ Circa 820 AD the abbot of Saint-Mihiel (the diocese of Verdun) argued that it is not enough to wait for guests to arrive, but we must seek them ourselves, so as to save them the trouble. There were also clear instructions on roads and paths' keeping. Thereby during the foggy or snowy weather or in the mountains, Christians were to welcome expected guests by meeting them outside, calling them or bell-ringing so that a newcomer would not get lost. Kitchens and pantries were to be wide open to visitors who were invited to the table. ${ }^{24}$ The Middles Ages was the period when new rules were formulated as regards housing guests of various social status. The rules varied depending on the social position of visitors with, where possible, separate houses or rooms for bishops, gentry and the poor. ${ }^{25}$

In Poland, visits of neighbours, friends and relatives have readily been welcome and expected all over centuries as good hospitality habits have always been diligently cultivated here. In the third part of Dziady [Forefathers' eve] drama, Adam Mickiewicz put the following words in the mouth of one of the men of letters gathered in the Warsaw Salon: "Our nation takes most pride in simple minds and hospitality." In the mid- $19^{\text {th }}$ century hospitality was regarded as "joy, need of life." Łukasz Gołębiowski wrote: "A Pole does not like eating alone so at his daily table, if only well-provided, always welcomes a visitor."26

22 N. Ohler, Życie pielgrzymów w średniowieczu. Między modlitwa a przygodą, przekł. M. Ruta, Kraków 2000, pp. 159-162.

23 Św. Benedykt z Nursji, Reguła. Tekst polsko-łaciński, Tyniec 1983, pp. 167-170.

24 Por. K. Potol, Gościnność w dziełach miłosierdzia, in: Hospitalitas consecrata..., pp. 91-111.

25 N. Ohler, Życie pielgrzymów..., pp. 170-172.

26 Ł. Gołębiowski, Domy i dwory, Lwów 1884, p. 78; cf. A. Merdas, “Gościu siądź pod mym liściem”, czyli o gościnności w przekazie literackim, in: Hospitalitas consecrata..., pp. 155-162. 
Sadly, hospitality started to lose its importance due to the ongoing atomization of social life, when each man began to face his troubles and solve his problems, as well as experience his joys and hope alone, unaccompanied by others. The hospitality acting space has been reduced to necessary meetings on greater occasions only to uphold family bonds and friendships. Man has found more competitive ways of relaxation and enjoyment, without family and closest friends. A more and more alienated guest has become a stranger, finally treated with cool indifference.

The table rituals, historically, geographically and socially diversified, no longer play an important role among people. Even traditional large tables have been replaced with low and uncomfortable "desks," with too few seats to welcome a bigger number of guests. Large tables have long been removed from private houses where they would take too much room. The table rituals have thus lost their customary position. ${ }^{27}$

\section{Mercy means sharing with others}

The Old Testament did not differentiate among free citizens, despite the disparities in their social status. The tendencies towards the equalization of rights and duties in all spheres of life were manifested through, for example, the prescripts regarding a tax imposed on a temple: "The rich shall not give more, and the poor shall not give less, than the half shekel, when you bring this offering to the Lord to make atonement for your lives." 28 The very fact of belonging to the class of the rich or the poor did not have any direct influence upon moral judgment. Every violation of the law was punished both, whether committed by the former or by the latter. Everybody owes justice to God, yet also to their brothers, both in personal and social relations. Prophet Isaiah denounced hypocrisy of those who zealously practiced the rituals of the religious cult, made blood sacrifices, and yet oppressed the weak and destitute. He admonished the faithful that their prayers would not be heard and denying justice would turn against them. ${ }^{29}$ Christianity has always

27 Cf. R. Marx, Kapitał. Mowa w obronie człowieka, przekł. J. Serafin, Kraków 2009, pp. 134-141; G. Witaszek, Amos. Prorok sprawiedliwości społecznej, Lublin 1996.

28 Exod 30:15.

29 Cf. Isa 1:11-17; 12. 
addressed the problem of people marginalized by poverty, treating them as a challenge and duty intertwined with the fulfilment of the commandment of love. ${ }^{30}$ St. Justin Martyr, c. $160 \mathrm{AD}$ observed: "And they who are well to do, and willing, give what each thinks fit; and what is collected is deposited with the president, who succours the orphans and widows and those who, through sickness or any other cause, are in want, and those who are in bonds and the strangers sojourning among us, and in a word takes care of all who are in need." 31

The most specific and the strictest guidance, as regards the destitute, is included in the Syrian Didascalia Apostolorum of the $3^{\text {rd }}$ century: "Make it your care and endeavour therefore to minister to widows out of the ministry of a clean conscience, that what they ask and request may be granted them at once upon their praying for it. But if there be bishops who are careless and give no heed to these matters, through respect of persons, or for the sake of filthy lucre, or because they neglect to make inquiry; they shall render no ordinary account. For they receive, forsooth, to administer for the nourishment of orphans and widows, from rich persons who keep men shut up in prison, or ill-treat their slaves, or behave with cruelty in their cities, or oppress the poor; or from the lewd, and those who abuse their bodies; or from evildoers; or from forgers; or from dishonest advocates, or false accusers; or from hypocritical lawyers; or from painters of pictures; or from makers of idols; or from workers of gold and silver and bronze (who are) thieves; or from dishonest tax-gatherers; or from spectators of shows; or from those who alter weights or measure deceitfully; or from inn-keepers who mingle water (with their wine); or from soldiers who act lawlessly; or from murderers; or from spies who procure condemnations; or from any Roman officials, who are defiled with wars and have shed innocent blood without trial: perverters of judgement who, in order to rob them, deal unjustly and deceitfully with the peasantry and with all the poor; and from idolaters; or from the unclean; or from those who practise usury, and extortions. Now they who nourish widows from these (sources) shall be found guilty in judgement in the day of the Lord; for the Scripture has said:

30 Św. Grzegorz z Nyssy, O miłości ku żebrakom. Mowa I, tłum. polskie, in: Św. Grzegorz z Nyssy, Wybór pism, Warszawa 1963, p. 169.

31 Justyn Męczennik, Apologia nr 67, in: M. Michalski, Antologia literatury patrystycznej, t. 1, Warszawa 1975, p. 97. 
'Better is a supper of herbs with love and amity than the slaughter of fatted oxen with hatred (Prov 15:17)."'32

In medieval disputes the subject of the poor re-emerged whenever the duty of almsgiving was discussed. This duty is to be fulfilled by those who have satisfied all their "necessary needs." Thomas Aquinas distinguishes two kinds of them:

1. everything which we may call today "existential minimum" - comprising an owner, his needs and the needs of his family and house members or workers, namely all those for whom he is obliged to care; almsgiving, derived from this part of revenues is not an obligation as it would imply depriving oneself, one's family and subordinates the livelihood; an exception is the situation when a person in need is the one on whom the future of the Church or of the state depends - then devoting one's life and the lives of the dependants is worthy all praise as the social good should prevail over one's own.

2. expenses related to performing a specific social function (social minimum) which St. Thomas Aquinas defines as conditio et status personae; however it is very difficult to specify status personae as it is quite varied; almsgiving derived from this part of revenues is not a duty of justice, yet it is praiseworthy. ${ }^{33}$

Until the $18^{\text {th }}$ century the Church had operated in the static and orderly society, determined by agriculture and craftsmanship, so it was the poverty from outside of the system which was the object of Christian concern. Charity-orientated congregations, hospitals, asylums, etc. were established in the times when countries no longer tried to undertake philanthropic activities. Thus the Church cared mainly for a "traditional" group of the poor: starving, sick, homeless, refugees, war and epidemic victims, widows and orphans. Up to the $19^{\text {th }}$ century these groups had constituted a prerogative social issue. The end of the medieval social order brought about severe structural crises, e.g. in the spheres of economy and society. They were intensified in the $19^{\text {th }}$ century due to industrial development and the emergence of new social problems: division of labour, the separation of labour and capital, treating labour as

32 Didaskalia, czyli katolicka nauka dwunastu Apostołów i świętych uczniów Zbawiciela naszego, rozdz. XVIII, in: M. Michalski, Antologia..., t. 1, p. 329.

33 K. Kowalski, Nauka św. Tomasza o miłosierdziu chrześcijańskim, Lwów 1932, pp. 6-19. 
a commodity, migration from the country to the city. There appeared the new forms of poverty and destitution, one of which associated with the so called worker issue. ${ }^{34}$

The Church social teachings evolved towards re-establishing and acknowledging the rights of every man who is in need. In his encyclical Mater et Magistra, Pope John XXIII stated most explicitly that: "The dignity of the human person 'normally demands the right to the use of the goods of the earth, to which corresponds the fundamental obligation of granting an opportunity to possess property to all if possible." 35

\section{The ethics of moderation}

The proposition of the ethics of moderation, or of a restraint in choices, entails deliberate orientation of man for performing the good in the name of those who live beyond the margin and outside the mainstream of social life. Many cultures have long propagated moderation as one of the responses to all possible offers the world makes to man. Moderation is justified by many arguments: social, religious, cultural, as an element of asceticism or as the key postulate of reason. Philosophy has produced its own peculiar ethos of moderation, be the antithesis of profligacy - manifesting itself through barbarity which does not know modesty and true simplicity. ${ }^{36}$

In The Nicomachean ethics, Aristotle introduced into philosophy the moral virtue of moderation as an ideal, later adopted by St. Thomas Aquinas and the entire Christian philosophy. The Latin term was medium virtutis, that is, "the mean of virtue." It is one of the most complex notions, establishing the mean as a golden rule between two extremes of emotions and acts. Therefore, profligacy is an excess in giving and deficiency in receiving, parsimony is an excess in receiving and a deficiency in giving. A "mean" consists in prudent

34 Cf. H. Domański, Nierówności społeczne, in: Słownik społeczny, red. B. Szlachta, Kraków 2004, pp. 740-751.

35 Pope John XXIII, Encyclical letter Mater et Magistra 114, http://w2.vatican.va/content/ john-xxiii/en/encyclicals/documents/hf_j-xxiii_enc_15051961_mater.html. Cf. S. Obirek, Postugiwać potrzebujacym. Rozmowa z ks. Tadeuszem Zaleskim-Isakowiczem, "Życie Duchowe" $2001 \mathrm{nr} 26$, pp. 31-36.

36 A. Waley, The book of songs, New York 1996, pp. 7-8, 18. 
and moderate giving and receiving. Nonetheless, it is extremely difficult to determine and measure it ${ }^{37}$ as a "mean" denotes "not too much" and "not too little," but "the right measure." It signifies in practice finding an in-between behaviour which saves man from extremes, both in the form of excess or deficiency. It is commonly known as a "golden rule," namely the proper moderation in various aspects of man's activity. Moderation differs, depending on specific situations which may cause shifting of "the mean's" borders, within the proper scope of changes. ${ }^{38}$ The above reflection on "the mean virtue" and "seeking a golden rule" in man's actions and aspirations, indicates the connection with the Christian virtues, particularly, with prudence, justice, temperance and love. Prudence (Latin: prudentia) signifies a virtue which allows man to use moderation in particular life situations. It is considered, first of all, to be the cause of all virtues, the mentor of them. That is why prudence is very often called "the charioteer of the virtues" (Latin: auriga virtutum) and it is associated with wisdom, foresight, sensibility and caution. Moderation is associated with justice. Plato rightly observed that justice of the soul depends on whether each part of the soul (reason, appetite and "spiritual part" dealing with the exemplary conduct as well as with anger and outrage) performs its own function. The consequence of the justice of the soul is justice in actions which may be described as moderation: to do injustice means to have more than one deserves, whereas to suffer the injustice means to have less than that. Justice, such understood, is a mean between causing injustice and being its victim..$^{39}$ The most concrete expression of moderation is the virtue of temperance, controlling oneself (sobriety, moderation - Latin: temperentia) which consists in the ability to have control over oneself with the help of sensory properties yet subjugating them to reason. It is very difficult, the more so, that it very often involves sensual pleasures. It is not only an ability to restrain one's bodily and emotional reactions (appetite, thirst, sexual desire) but also to govern the entire sensual and emotional sphere. Temperance is thus the condition of man's freedom. ${ }^{40}$

37 Por. A. MacIntyre, Krótka historia etyki, przekł. A. Chmielewski, Warszawa 1995, pp. 103-107.

38 T. Ślipko, Etos chrześcijański. Zarys etyki ogólnej, Kraków 1974, pp. 333-335.

39 A. MacIntyre, Krótka historia etyki..., pp. 75-76, 120.

40 Cf. Jan Paweł II, Cnota wstrzemięźliwości. Audiencja generalna 24 X 1984, in: Nauczanie papieskie 1984, t. 7, cz. 2, Poznań 2002, pp. 504-506 (English version: https://www.ewtn.com/ 
The analysis of moderation entails its association with the virtue of love (charity) - pursuing for and aspiring to good. It is the prime and strongest justification of the quest for moderation. It may manifest itself through seeking the good for oneself (self-love) or making good for others (love of a neighbour). From this union of love and good derives another love quality, that is, generosity since love is not confined to doing an exact measure of good (like justice); rather it seeks its maximization - it aims at giving as much as possible, going beyond the necessary and giving of its own free will, as much as prudence allows. ${ }^{41}$

This union of love and generosity is how the Church understands her service in the world. Caring for the poor comes from a strong conviction that terrestrial goods are for all as it is what justice is about. It also comes from the belief in unity of people. When using the goods offered by the world, man should mind that they cannot serve only himself, but that other people as well might benefit from them. Poverty results from the injustice manifesting itself through underdevelopment and shameful exploitation. The so called preferential love for the poor is connected with the science of man's personal dignity and with the example of God, who first loved people. ${ }^{42}$

One of the key issues raised during the discussions on the condition of the modern world is ecology. It is within this area in which the virtue of moderation has gained a new, social meaning. The major idea of ecological disputes is environment, that is, a natural surrounding which interacts with organisms living in it. Environment consists of both, natural and industrialized - changed by man - components, usually interdependent in such a way that one change entails another in the rest of the system. The world is a global reality in which the whole human family lives and acts. Therefore, the world is an environment in which the population of people lives and which they transform through their work. Man is a unique element of the natural environment. He regards the environment as the provider of food and natural resources. The goods acquired and possessed

library/PAPALDOC/jp2tb123.htm [1.12.2016]); Jan Paweł II, Wstrzemięźliwość jako warunek wolności, Audiencja generalna 7 XI 1984, in: Nauczanie papieskie 1984, t. 7, cz. 2, pp. 585586 (English version: https://www.ewtn.com/library/PAPALDOC/JP841107.htm [01.12.2016]).

41 T. Ślipko, Etos chrześcijański..., pp. 340-343.

42 Cf. W. Przygoda, Ubodzy jako przedmiot postugi charytatywnej Kościoła, "Roczniki Naukowe Caritas" 1998 nr 2: Ubóstwo, pp. 93-113. 
by man, his happiness and health cannot be excluded from a wide social (sociosphere) and environmental contexts (biosphere, geosphere, heliosphere and cosmosphere). The most serious crisis, to have been taken place in industrial societies, is the loss of sense and purpose of human actions. It is tragic - as argued by Willis W. Harman, the professor the Californian Stanford Research Institute - that the contemporary science has nothing to say about the values and aims as it is devoid of ecological conscience. ${ }^{43}$

The great pro-ecological civilization has been replaced with scientific and mechanical one. The religious tradition no longer is a regulator and a guarantee of proper interrelations between people and the environment, and among people themselves. There has occurred a split between intellectual attainments and the emotional and moral sphere of man. Mechanisms, that is, the concept of the world as a wholeness, to be defined only by the laws of mechanics, has become a prevailing philosophy - determining the ways of viewing the environment, treated exclusively in quantitative and utilitarian categories.

\section{The sustainable development of the world unity}

Among many endeavours to create a holistic programme for the world there is the idea of "sustainable development." It is the concept developed by the World Commission on Environment and Development (UN). The definition of "sustainable development" has been presented in the so called Brundtland Report of 1987 and it reads: "Sustainable development is development that meets the needs of the present without compromising the ability of future generations to meet their own needs." 44

Sustainable development requires the unification of three basic elements: ecological, economic and social. The social goal is to reach the state of equitable redistribution of natural resources or at least equitable chances to redistribute them. It is not thus the sole "sustainable development," but rather "sustainable and just," or so to speak, "moderate" or ecological-and-social. It ought to consider the situation of the impoverished parts of the world. Nonetheless,

43 J. Aleksandrowicz, Sumienie ekologiczne, Warszawa 1988, pp. 54, 125-127.

44 Cf. E. Kośmicki, Status społecznie zorientowanych badań nad środowiskiem. Problem koncepcji “trwałego rozwoju”, Poznań 1997, pp. 165ff. 
if the objectives of this programme are to be fulfilled, it seems imperative to introduce economic and social changes, as well as changes in awareness in the entire modern world. ${ }^{45}$ The UN Summit of 2000 set the Millennium Development Goals. Thereby the participating world leaders declared that by the year 2015 they will have reduced by half the percentage of people living in extreme poverty (i.e. on less than $\$ 1.25$ a day); halved the proportion of people who suffer from hunger; ensured that children everywhere will be able to complete a full course of primary schooling; eliminated gender disparity in primary, secondary and tertiary education; reduced by two thirds the under-five mortality rate; reduced by three quarters the maternal mortality ratio; combated and reduced HIV/AIDS, malaria and other diseases; halved the proportion of people without sustainable access to safe drinking water. ${ }^{46}$ Needless to say, these noble aims and postulates have still remained the acts of a good will... and nothing more. Luc Boltanski, a co-author of the thoroughly rendered analysis of the globalized capitalism, conducted and published the study on the so called "distant suffering." In the case of suffering observed from the distance or known only by hearsay, it is difficult to be open and understanding, not to mention taking any kind of responsibility. It is then easier to excuse oneself, to refrain from any action, to absolve oneself of passivity. The moral maturity of the modern man does not keep pace with numerous and newly-arising economic interrelations which entangle the globe. It is still a challenge to develop "the universe of moral obligations" for the mankind. ${ }^{47}$

The problem of poverty, still neglected by the international bodies, despite the programme for the world development, is a huge challenge also for the Christian thought, the more so that the concept of the "sustainable development" reveals the need to conform to the religious ideals. Preserving the order of nature will only be possible if man regulates his inner self, and this may be achieved through faith. ${ }^{48}$

45 E. Kośmicki, Antropologia ekologiczna w warunkach "trwałego rozwoju”, "Przegląd Oświatowy" 1998 nr 5 (165), pp. 23-24.

46 P. Singer, Miliarderzy, podzielcie się!, "Gazeta Wyborcza. Świąteczna” 30 December 2006 - 1 January 2007, p. 13.

47 E. Isakiewicz, Dobro kalkulowane. Rozmowa z prof. Zygmuntem Baumanem, "Newsweek Polska" 2007 nr 27, pp. 74-75.

48 J. M. Dołęga, W kierunku nowej cywilizacji, in: Światopogląd i ekologia. Materiały III Olsztyńskiego Sympozjum Ekologicznego Olsztyn - Waplewo 11 - 13 września 199 6, red. J. Dębowski, Olsztyn 1997, pp. 32-42. Cf. Jan Paweł II, O solidarność z głodującymi. Przesłanie do 
Continence, in the Catholic teachings, is called "self-restraint" and it is connected with the fact that in order to control lusts and desires of the body, man cannot cross the moral boundaries whether alone or in relations with others. Continence in goods consumption seems to be one of the aspects of the everlasting quest for the full humanity ${ }^{49}$ It is also one of the crucial aspects of evangelical love which does not allow to ignore people in need, hungry and thirsty. "The common table" of the earth cannot be unlawfully appropriated by the more powerful and shrewder, especially when it comes to the goods indispensable for life and health.

In the long conflict between poverty and wealth, aggravated by the last centuries' revolutions and political unrests, the most appropriate attitude to be adopted by those concerned with the fate of the world, is invariably mercy. According to the Church teaching, the primary purpose of all economic and financial systems should be service to man, satisfying his needs, producing the goods guaranteeing him decent life. The economic aim is aptly described in Pope Pius XI's encyclical letter Quadragesimo Anno: "For then only will the social economy be rightly established and attain its purposes when all and each are supplied with all the goods that the wealth and resources of nature, technical achievement, and the social organization of economic life can furnish. And these goods ought indeed to be enough both to meet the demands of necessity and decent comfort and to advance people to that happier and fuller condition of life which, when it is wisely cared for, is not only no hindrance to virtue but helps it greatly."50

dyrektora generalnego FAO z okazji Światowego Dnia Wyżywienia, "L’Osservatore Romano", edycja polska $2001 \mathrm{nr} 1$ (229), p. 9 (English version: http://w2.vatican.va/content/john-paul-ii/ en/speeches/1997/november/documents/hf_jp-ii_spe_19971108_xxix-conf-fao.html).

49 Jan Paweł II, Cnota umiarkowania. Audiencja generalna, Rzym 22 XI 1978, in: Nauczanie papieskie 1978, t. 1, Poznań 1987, pp. 86-88 (English version: https://w2.vatican.va/content/john-paul-ii/en/audiences/1978/documents/hf_jp-ii_aud_19781122.html); Jan Paweł II, Wezwani do dzielenia się stołem stworzenia. Orędzie na Wielki Post 1992, 29 June 1991, "L'Osservatore Romano", edycja polska $1992 \mathrm{nr} 5$ (142), p. 4 (English version: https://w2.vatican.va/content/ john-paul-ii/en/messages/lent/documents/hf_jp-ii_mes_29021992_lent-1992.html).

50 Pope John XXIII, Encyclical letter Quadragesimo Anno of on reconstruction of the social order, 75, https://w2.vatican.va/content/pius-xi/en/encyclicals/documents/hf_p-xi_ enc_19310515_quadragesimo-anno.html. 


\section{Bibliography}

Aleksandrowicz J., Sumienie ekologiczne, Warszawa 1988.

Benedykt z Nursji św., Reguła. Tekst polsko-łaciński, Tyniec 1983.

Dąbrowski E., Nowy Testament na tle epoki. Geografia - historia - kultura, Poznań 1965.

Didaskalia, czyli katolicka nauka dwunastu Apostołów i świętych uczniów Zbawiciela naszego, rozdz. XVIII, in: M. Michalski, Antologia literatury patrystycznej, t. 1, Warszawa 1975, p. 329.

Dołęga J. M., W kierunku nowej cywilizacji, in: Światopoglad i ekologia. Materiały III Olsztyńskiego Sympozjum Ekologicznego Olsztyn - Waplewo 11-13 września 1996, red. J. Dębowski, Olsztyn 1997, pp. 32-42.

Domański H., Nierówności społeczne, in: Słownik społeczny, red. B. Szlachta, Kraków 2004.

Gołębiowski Ł., Domy i dwory, Lwów 1884.

Grzegorz z Nyssy św., O miłości ku żebrakom. Mowa I, tłumaczenie polskie in: św. Grzegorz z Nyssy, Wybór pism, Warszawa 1963.

Isakiewicz E., Dobro kalkulowane. Rozmowa z prof. Zygmuntem Baumanem, “Newsweek Polska” 2007 nr 27, pp. 74-75.

Jan Paweł II, Cnota umiarkowania. Audiencja generalna, Rzym 22 XI 1978, in: Nauczanie papieskie 1978, t. 1, Poznań 1987, pp. 86-88.

Jan Paweł II, Cnota wstrzemięźliwości. Audiencja generalna 24 X 1984, in: Nauczanie papieskie 1984, t. 7, cz. 2, Poznań 2002, pp. 504-506.

Jan Paweł II, O solidarność z głodującymi. Przesłanie do dyrektora generalnego FAO z okazji Światowego Dnia Wyżywienia, "L'Osservatore Romano", edycja polska $2001 \mathrm{nr} 1$ (229), p. 9.

Jan Paweł II, Wezwani do dzielenia się stołem stworzenia. Orędzie na Wielki Post 1992, Watykan 29 VI 1991, "L'Osservatore Romano”, edycja polska 1992 nr 5 (142), p. 4.

Jan Paweł II, Wstrzemięźliwość jako warunek wolności. Audiencja generalna 7 XI 1984, in: Nauczanie papieskie 1984, t. 7, cz. 2, Poznań 2002, pp. 585-586. Justyn Męczennik, Apologia, No. 67, in: M. Michalski, Antologia literatury patrystycznej, t. 1, Warszawa 1975, p. 97.

Kośmicki E., Antropologia ekologiczna w warunkach "trwałego rozwoju”, "Przegląd Oświatowy” 1998 nr 5 (165), pp. 23-24. 
Kośmicki E., Status społecznie zorientowanych badań nad środowiskiem. Problem koncepcji "trwałego rozwoju”, Poznań 1997.

Kowalski K., Nauka św. Tomasza o miłosierdziu chrześcijańskim, Lwów 1932.

MacIntyre A., Krótka historia etyki, przekł. A. Chmielewski, Warszawa 1995.

Marx R., Kapitał. Mowa w obronie człowieka, przekł. J. Serafin, Kraków 2009.

Merdas A., "Gościu siądź pod mym liściem”, czyli o gościnności w przekazie literackim, in: Hospitalitas consecrata, red. K. Wójtowicz, Kraków 2003, pp. 155-162.

Mikucki K., Od obcego do gościa. Refleksje socjologiczno-filozoficzne, in: Hospitalitas consecrata, red. K. Wójtowicz, Kraków 2003, pp. 56-68.

Mounier E., Wprowadzenie do egzystencjalizmów, tłum. A. Bukowski, E. Krasnowolska, Kraków 1964.

Obirek S., Posługiwać potrzebującym. Rozmowa z ks. Tadeuszem Zaleskim-Isakowiczem, “Życie Duchowe” 2001 nr 26, pp. 31-36.

Ohler N., Życie pielgrzymów w średniowieczu. Między modlitwa a przygoda, przekł. M. Ruta, Kraków 2000.

Paciorek A., Obyczajowość życia wspólnotowego, in: Życie społeczne w Biblii, red. G. Witaszek, Lublin 1997, pp. 314-320.

Popielowski W., Gościnność w ikonach i nakazach biblijnych, in: Hospitalitas consecrata, red. K. Wójtowicz, Kraków 2003, pp. 38-55.

Potol K., Gościnność w dziełach miłosierdzia, in: Hospitalitas consecrata, red. K. Wójtowicz, Kraków 2003, pp. 91-111.

Przygoda W., Ubodzy jako przedmiot postugi charytatywnej Kościoła, "Roczniki Naukowe Caritas" 1998 nr 2: Ubóstwo, pp. 93-113.

Pytel J. K., Pojęcie gościnności w literaturze biblijnej, "Ruch Biblijny i Liturgiczny” 1977 nr 30, pp. 174-179.

Rodziński A., Osoba. Moralność. Kultura, Lublin 1989.

Schelkle K. H., Teologia Nowego Testamentu, tłum. M. L. Dylewski, Kraków 1984.

Singer P., Miliarderzy, podzielcie się!, “Gazeta Wyborcza. Świąteczna” 30 December 2006 - 1 January 2007, p. 13.

Ślipko T., Etos chrześcijański. Zarys etyki ogólnej, Kraków 1974.

Waley A., The book of songs, New York 1996.

Witaszek G., Amos. Prorok sprawiedliwości społecznej, Lublin 1996.

Wojtyła K., Rozważania o istocie człowieka, Kraków 1999.

Wojtowicz H., Gościnność, in: Encyklopedia katolicka, t. 5, Lublin 1989, k. 1334-1335. 